\title{
Phytopathology
}

\section{Spicing Up the $N$ Gene: F. O. Holmes and Tobacco mosaic virus Resistance in Capsicum and Nicotiana Plants}

\author{
Karen-Beth G. Scholthof
}

Department of Plant Pathology and Microbiology, Texas A\&M University, College Station, TX 77843-2132.

Accepted for publication 9 September 2016.

\begin{abstract}
One of the seminal events in plant pathology was the discovery by Francis O. Holmes that necrotic local lesions induced on certain species of Nicotiana following rub-inoculation of Tobacco mosaic virus (TMV) was due to a specific interaction involving a dominant host gene ( $N$ ). From this, Holmes had an idea that if the $N$ gene from $N$. glutinosa was introgressed into susceptible tobacco, the greatly reduced titer of TMV would, by extension, prevent subsequent infection of tomato and pepper plants by field workers whose hands were contaminated with TMV from their use of chewing and smoking tobacco. The ultimate outcome has many surprising twists and turns, including Holmes' failure to obtain fertile crosses of $N$. glutinosa $\times N$. tabacum after 3 years of intensive work. Progress was made with $N$. digluta, a rare amphidiploid that was readily crossed with $N$. tabacum. And, importantly, the first demonstration by Holmes of the utility of interspecies hybridization for virus resistance was made with Capsicum (pepper) species with the identification of the $L$ gene in Tabasco pepper, that he introgressed into commercial bell pepper varieties. Holmes' findings are important as they predate Flor's gene-for-gene hypothesis, show the use of interspecies hybridization for control of plant pathogens, and the use of the local lesion as a bioassay to monitor resistance events in crop plants.
\end{abstract}

Plant pathologists have had many success stories in the past century in controlling plant diseases. One of the best known is that of employing $N$-gene-mediated resistance, a fundamental advance providing a means by which plant pathologists could control the ravages of Tobacco mosaic virus (TMV) infections in host plants. This discovery is seemingly linear and straightforward: in the 1930s, Francis O. Holmes introgressed the $N$ gene from Nicotiana glutinosa into commercial tobacco ( N. tabacum) cultivars. Yet, as is often the case, the events leading up to this success are less straightforward-and more interesting — with several experimental dead-ends and detours before the goal of interspecies hybridization and introgression of the $N$ gene was realized in commercial tobacco cultivation.

What is particularly intriguing is that Holmes was not per se interested in protecting tobacco from TMV losses; instead, his intent was to move the $N$ gene into commercial tobacco lines for a particular-even peculiar-reason: to reduce the amount of TMV in the environment and thus protect pepper and tomato crop plants from infection. As Holmes explained, tobacco leaves were loaded

Corresponding author: K.-B. G. Scholthof; E-mail address: kbgs@tamu.edu

*The $\boldsymbol{e}$-Xtra logo stands for "electronic extra" and indicates that two supplementary figures are published online.

(C) 2017 The American Phytopathological Society with TMV. Field workers, as a result of using tobacco products, inadvertently transferred TMV to young pepper and tomato transplants. Holmes had an idea that incorporation of the $N$ gene into tobacco would reduce TMV inoculum to nearly undetectable levels, workers would no longer transfer virus from tobacco products, and vegetable crops would be protected from disease losses (Fig. 1). From this, yield losses in pepper and tomato fields might be controlled by introgression of the $N$ gene from $N$. glutinosa into commercial tobacco varieties ( $N$. tabacum) preventing tobacco from being a bridging host for subsequent infections of tomato and pepper crops.

In time, moving the $N$ gene to commercial tobacco lines was successful, yet there was great difficulty in these efforts, leading Holmes to experiment with other solanaceous plants. Consequently, his first success in developing TMV resistance was with Capsicum annuum (bell pepper) by introgression of the $L$ gene from Tabasco pepper (C. frutescens). Subsequently, he was finally able to transfer the $N$ gene from $N$. glutinosa to commercial tobacco, but only after obtaining $N$. digluta. This was an exceeding rare amphidiploid-a fertile plant with both parental diploid chromosomes - identified by the geneticists Thomas Harper Goodspeed and Roy E. Clausen, at the University of California-Berkeley, who were interested in the evolutionary taxonomy of the genus Nicotiana. Here I provide a narrative of the idea that Holmes had, based on his intensive work on TMV and its solanaceous hosts, that in some plants necrotic local lesions associated with rub-inoculation of TMV to leaves 
was due to a host genetic factor that was induced in response to TMV infection, and this genetic factor could be transferred from the lab to the field to protect economically important crops from disease.

\section{TOBACCO MOSAIC VIRUS-BACKGROUND}

In 1898, Martinus W. Beijerinck reported that tobacco plants with mosaic disease (Fig. 2), having symptoms of yellowing (chlorosis) and leaf mottling, harbored an infectious agent-a contagium vivum fluidum (Scholthof et al. 1999; Zaitlin 1998). This agent, collected as flow-through in a Chamberland filter that typically retained bacteria, recapitulated the symptoms associated with the mosaic disease when rub-inoculated onto a susceptible host plant. In his work, Beijerinck used the term "virus" to mean something specific: an infectious agent smaller than bacteria and not visible by the use of light microscopy. From this, in time, the etiological agent was named Tobacco mosaic virus. Yet for another 30 years there was much confusion and discussion about the nature of this filterable virus: Was it a small bacterium? A physiological disorder? An enzyme? I and others have elaborated on the early work on TMV and the efforts to place viruses within the rubric of microbiology (Creager 2002; Scholthof 2004; Scholthof 2011, 2014; Scholthof and Peterson 2006; Scholthof et al. 1999; Summers 2014; van Helvoort 1991, 1993, 1996).

As I have reported previously, Holmes developed several tools and techniques that were critical for the biochemical determination of the nature of TMV (Scholthof 2000, 2004; Scholthof 2011, 2014; Scholthof and Peterson 2006; Scholthof et al. 1999). Holmes had trained as a protozoologist at Johns Hopkins University, completing a dissertation on a protozoan of milkweed plants (Holmes 1925, 1928a). He began his professional career at the Boyce Thompson Institute for Plant Research (BTI) at Yonkers, New York, in 1924, under the direction of Louis O. Kunkel. In 1932, most of Kunkel's virology group, including Holmes, joined the Rockefeller Institute for Medical Research (RIMR) at Princeton, New Jersey (Scholthof and Peterson 2006). Holmes remained with RIMR-Princeton until 1950, at which time he and the other scientific staff were transferred to RIMR in New York City. He retired in 1965, the same year RIMR became Rockefeller University.

At the BTI, Holmes was tasked with determining the "nature of the mosaic disease" of tobacco. He spent 3 years attempting to visualize the virus by ultra-light microscopy. Eventually, Holmes realized that he needed to determine if there was even enough of the ill-defined agent in his samples to be detected by microscopy (Scholthof 2011, 2014; Scholthof and Peterson 2006). From this, Holmes developed a biological assay to detect minute quantities of the virus in tobacco (Nicotiana) species. He showed that necrotic or chlorotic lesions could be used to monitor TMV infection, instead of the whole plant systemic assays used previously (Fig. 3). Holmes selected $N$. glutinosa for the bioassays because of its rapid response ( 2 to 3 days) to TMV infection-revealed as small, dark brown necrotic local lesions that restricted the virus to the inoculated leaf. In a series of experiments he showed the utility of using the local lesion as a biological assay to study host range, virus titer, and movement (Holmes 1928b, c, d, 1929a, b, 1930, 1931), a method that was quickly adopted by the TMV community (Scholthof 2014).

\section{HOST PLANT RESPONSES TO TMV INFECTION}

Significant economic losses were associated with TMV infections of tobacco, pepper, and tomato plants in the early 20th century in the United States. Then as now, typical control measures included (i) removing obviously diseased plants from the field and (ii) not using seed from infected plants-strategies that were "of a temporary and palliative nature" (Holmes 1954). Holmes had an idea that the local lesion response of $N$. glutinosa to TMV infection was the result of a dominant gene (gene $N$, for the necrotic local lesion). Furthermore, Holmes was the first to describe a virus as "hereditary unit" which had a measurable value that could be used to study plant genetic inheritance and also be of practical value for farmers (Holmes 1934b). From this, he "soon found himself interested in the genetic aspects of plant virus diseases" and by 1934 "devoted his chief attention ... [to] heritable susceptibility to infection" (Corner 1964). Contextually, the TMV N-gene research performed by Holmes is representative of the advances in Mendelian genetics in American agriculture in the early 20th century (Allen 1991; Campbell et al. 1999; Fitzgerald 1990; Kimmelman 1987; Kloppenburg 1985; Rosenberg 1977, 1997; Rossiter 1975).

\section{BREEDING FOR RESISTANCE IN THE UNITED STATES}

Ernest B. Babcock (Smocovitis 2009) and Roy E. Clausen taught the first modern genetics course at Berkeley and coauthored Genetics in Relation to Agriculture, published in 1918 (and a revised edition in 1927) (Babcock and Clausen 1918). A single chapter was devoted to experimental and practical strategies to

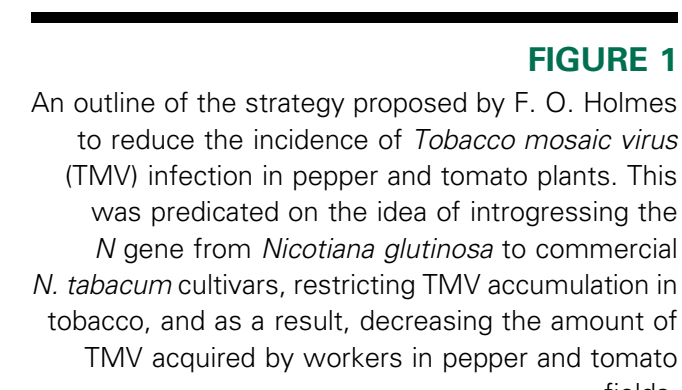

fields.

\section{Situation in 1930s:}

TMV-infected tobacco plants

Tobacco products have TMV

(cigarettes, chewing tobacco)

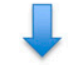

Field workers' hands contaminated with TMV from using tobacco products

Field workers unknowingly infect young tomato and pepper plants

Field pepper and tomato yield losses of $50-100 \%$

\section{Holmes' Idea (1931):}

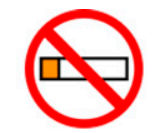

$N$ gene tobacco products will have essentially no TMV (cigarettes, chewing tobacco)

High yielding pepper and tomato fields

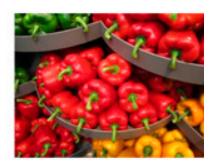

New Jersey is not a tobacco-growing state. Holmes' idea was to prevent spread of virus to pepper/tomato from tobacco products (cigarettes, etc.) used by field workers. 
breed crop plants for resistance to plant diseases, although there was no mention of viruses or control of viral diseases. They summarized the successes with disease control and concluded that "these few cases, taken almost at random ... amply justify the recommendation that the breeding of disease-resistant varieties of economic plants by hybridization and selection should receive more attention from plant pathologists and horticulturists in the future" (Babcock and Clausen 1918). In both editions of their textbook, Babcock and Clausen cautioned against the old pre-Mendelian method of selection in the field for a single plant variety to look for disease resistance. Instead "the scientific plan of procedure is to undertake variety testing on a large scale preparatory to hybridization of the most promising forms" (Babcock and Clausen 1918). The primary stumbling block was that little was known about the genetics of the pathogens. Plant pathology was a relatively new discipline in the life sciences and the pathologists, working primarily at land grant universities or for the U.S. Department of Agriculture (USDA), were being pushed for solutions to protect plants from plant diseases (Campbell et al. 1999).

Of course, host resistance had been shown to control rust pathogens on wheat, based on the leadership by E. C. Stakman at the University of Minnesota (Christensen 1984; Peterson 2001, 2003). Typically, wheat lines that displayed lesser effects following inoculation with Puccinia graminis-either necrotic or chlorotic lesions-were crossed with wheat lines that had good agronomic qualities. These crosses produced F1 plants resistant to infection. The F1 plants were backcrossed to the agronomically important parent for successive generations until most of the sought after grain qualities and habit of the plant were restored. This was the scientific or Mendelian breeding scheme that was developed by R. H. Biffen in England by 1907 and, thereafter, pursued with great enthusiasm by American plant pathologists. Not only was wheat breeding a success, but also breeding for pathogen resistance in many economically important crops including cotton, rubber, potato, grape, and beans. Yet this was following from breeder-mediated selection, not an evolutionarily anchored methodology to develop robust, genetically resistant crop plants.

The need for new technology to protect plants from virus diseases was a priority for plant pathologists. There were no chemical controls and insecticides were impractical or not efficacious for controlling the insect vectors that spread plant viruses. That viruses could be symptomless in host plants presented an additional problem as horticultural cuttings, trimming, or even walking through a field could easily transmit viruses from plant to plant. Once a plant had a virus infection the choice was to rogue (remove) the diseased plant or have it "serve as a point of infection to nearby healthy individuals" with concomitant economic losses (Holmes 1954). Holmes wanted to move forward with a new, focused strategy for genetic resistance to TMV by interspecies hybridization.

\section{TMV AND SOLANACEOUS PLANTS}

For plant pathologists, the canonical account of $N$-gene resistance in commercial tobacco is linear and straightforward: Holmes moved the $N$ gene from $N$. glutinosa to commercial tobacco rendering the tobacco resistant to TMV-which was of great use to the tobacco grower. There are at least two problems with this narrative. First, based on his own writing, introgression of the $N$ gene into commercial tobacco lines was to solve a particular problem: to reduce the amount of TMV in the environment (i.e., in tobacco) and thus protect pepper and tomato plants from infection. The purpose was not to produce a product for tobacco growers. Second, introgression of the $N$ gene into $N$. tabacum was neither straightforward, as I narrate below, nor the first successful example of breeding for TMV resistance. Instead, the demonstration that a dominant gene for TMV resistance could be successfully deployed in a crop plant was first shown for pepper (Capsicum spp.).
FIGURE 2

Tobacco mosaic virus (TMV) infections of tobacco and tomato. A, Tobacco from "Double Happiness" cigarettes (China) was rub-inoculated to two lower leaves of a Nicotiana tabacum 'Glurk' plant. This cultivar has the $N$ gene introgressed into an $N$. tabacum 'Turkish' background. B, On the leaf marked with a rectangle, necrotic local lesions have formed 5 days after inoculation (dark brown circles, primarily on the right half of the leaf), thus restricting the virus infection to a few cells. The inset shows fine detail of the necrotic local lesions. C, The necrotic local lesions, having formed a barrier, prohibit cell-to-cell movement of TMV and protect the plant from systemic infection. Note that the circled leaf in panel $\mathrm{C}$ is the same leaf as in panel B, showing an inoculated leaf with the necrotic local lesion in response to TMV inoculation. D, A field-grown tobacco plant lacking the $N$ gene is susceptible to systemic TMV infection. The

plant is stunted and the leaves are deformed and develop a yellow-green mottle (mosaic). E and F, A tomato plant infected with TMV displays strong mosaic symptoms on the infected leaves and fruit. TMV infection can reduce both yield and market value of tomatoes. Holmes identified wild tobacco, pepper, and tomato plants with genes for resistance to TMV that were subsequently introgressed into commercial varieties of these plants-genes that remain in use today. (Panels $D, E$, and $F$ are reproduced with permission of The American Phytopathological Society.)
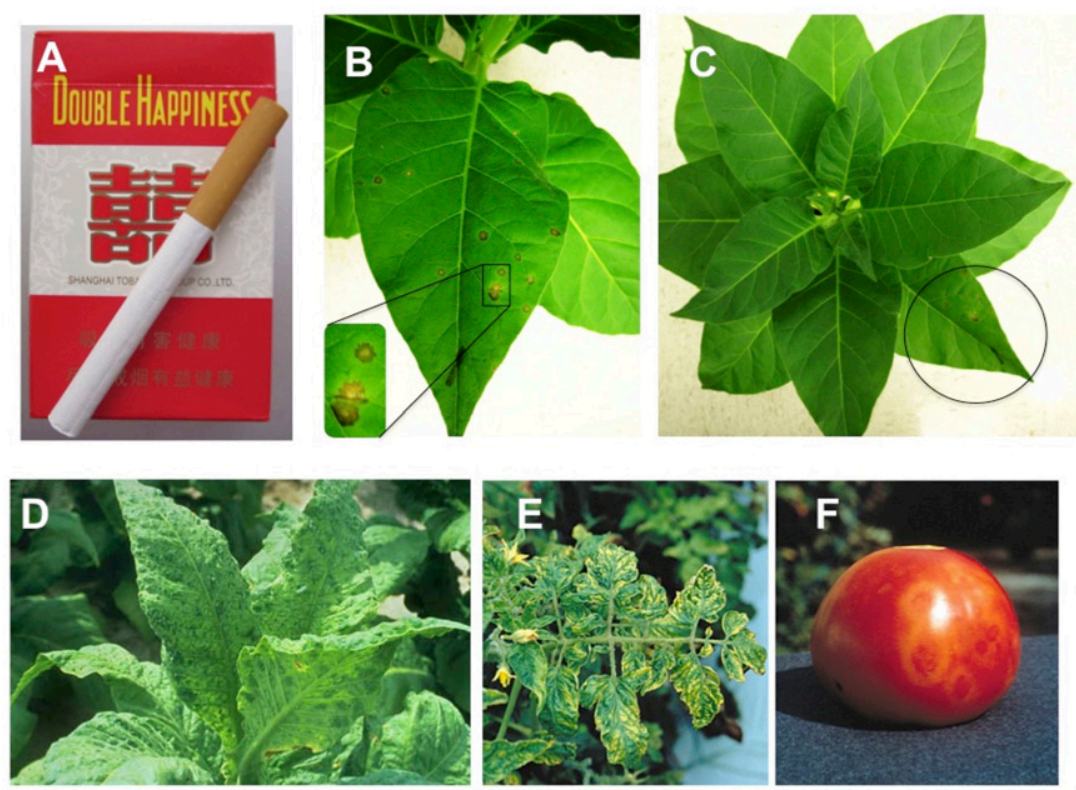
Holmes experimented with many plants in the family Solanaceae. This included peppers-ranging from sweet bell peppers (Capsicum annuum) to pungent Tabasco pepper (C. frutescens). In 1931, Holmes made a "limited survey" of pepper fields in New Jersey, finding TMV prevalent and the disease pressure high, resulting in "considerable loss" of yield (Holmes 1932). This was, according to Holmes, the first systematic study of the effects of TMV on vegetable crops. It soon became apparent that TMV was economically devastating, accounting for the loss of upwards of $50 \%$ of the tomato crop and up to $100 \%$ losses in pepper fields. Holmes had an innovative, original idea without precedent in plant pathology, just not the exact one told today by plant scientists. Although New Jersey was not a tobacco growing state, tomato plants were consistently infected with TMV from year-to-year. Holmes reasoned that the introduction of TMV was likely facilitated by field workers who were using tobacco products (cigarettes, chewing tobacco, etc.) (Fig. 2). Holmes had proposed a powerful new strategy to control plant virus diseases, using the tools of Mendelian genetics, observations about farm practices, and the detailed study of TMV infection (Fig. 1). As explained by W. D. Valleau, a University of Kentucky plant pathologist, with $N$-gene resistance "any chewing or smoking tobacco from the crop ... would be virus free, and the second-year crop should be entirely uninjured by the virus thus reducing the overall levels of virus and the potential for subsequent transfer to pepper and tomato crops" (Valleau 1942).

\section{NICOTIANA INTERSPECIES HYBRIDIZATION}

Holmes was connecting disparate areas of research, writing that TMV "because of its easy manipulation as a hereditary unit may be a potentially useful tool in attempting to gain an understanding of the nature of viruses" (Holmes 1934b). His thinking was increasingly focused on strategies for breeding plants for resistance

\section{FIGURE 3}

An example of the extensive survey of host responses to Tobacco mosaic virus (TMV) in solanaceous plants reported by F. O. Holmes in 1931. The original figure legend: "Leaves of Nicotiana tabacum variety Turkish [a susceptible host] stained in iodine to show local lesions [on inoculated leaves] (A) 2 days, (B) 3 days, and (C) 4 days after inoculation. Portions of living leaves showing necrotic local lesions in (D) N. glutinosa, (E) N. rustica, (F)

N. langsdorffii, (G) N. sanderae, $(\mathrm{H})$ N. acuminata, (I) N. glutinosa $\times$ glauca, (J) Capsicum annum [sic] variety Anaheim Chili, (K) Solanum pseudocapsicum, (L) S. melongena [eggplant] variety Black

Beauty, (M) Nicotiana alata, (N) Datura stramonium, (O) Phaseolus vulgaris variety Early Golden Cluster" (Holmes 1931).

(Reproduced with permission of the Boyce Thompson Institute.)

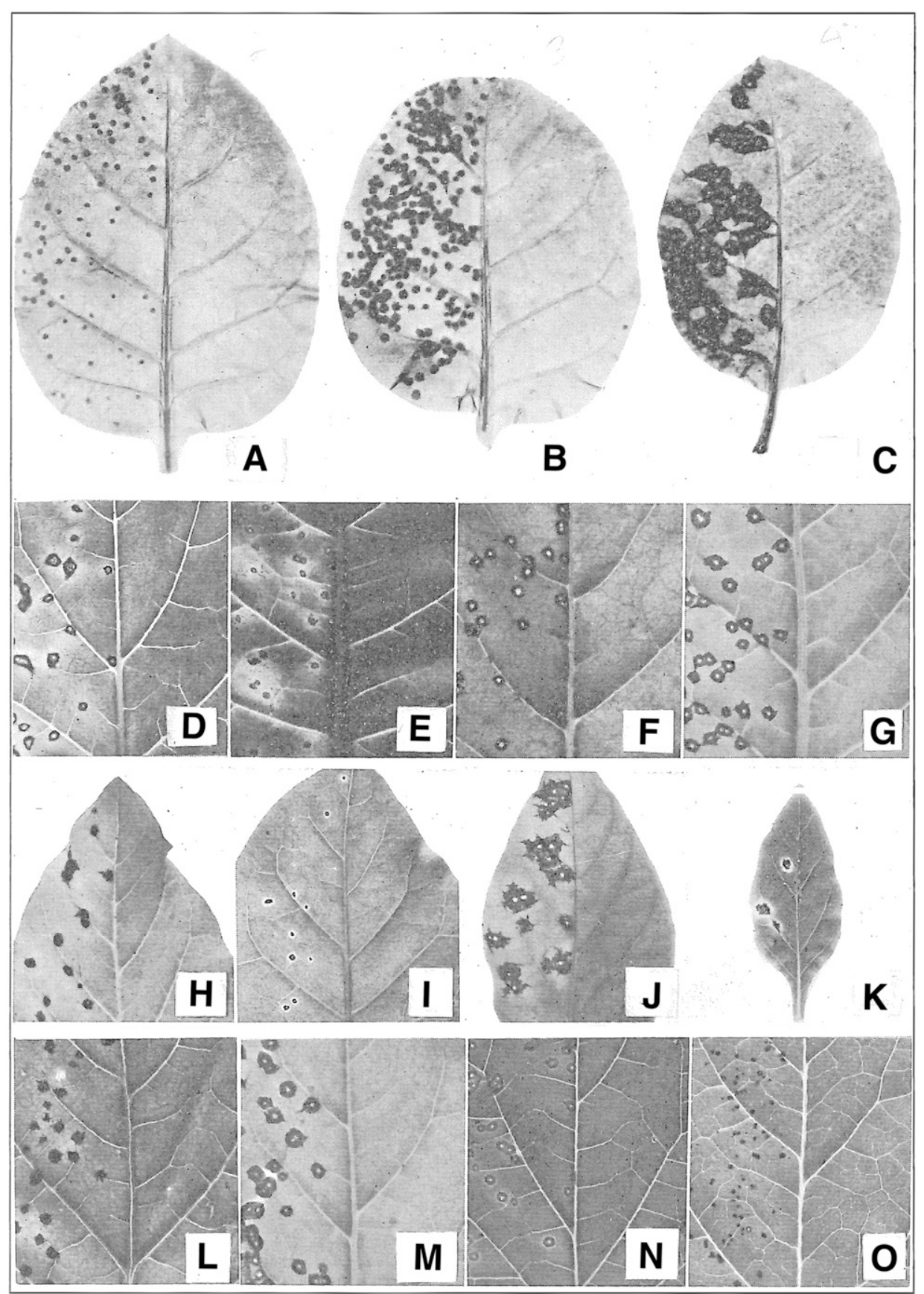


to TMV, drawing on his knowledge that a "plant that possesses the dominant character [resistance] is able to restrain tobacco-mosaic virus from producing a systemic infection" (Holmes 1934b).

Toward achieving his goal, plants of $N$. tabacum $\times N$. glutinosa, were "grown continuously in greenhouse and garden, often in considerable numbers, for more than 3 years. During this period the (F1) hybrid proved consistently self-sterile and sterile to all tested pollens" (Holmes 1938a). This same outcome had been reported in 1914, by H. A. Allard, a USDA plant physiologist, who had crossed $N$. tabacum varieties with pollen from $N$. glutinosa (then known as N. viscosum) (Scholthof 2004). The F1 plants, that closely resembled the $N$. tabacum parent, were considered immune to TMV infections, but were infertile (Allard 1914, 1916). Allard also was the first to expand the host range of TMV by inspection of systemic symptoms on tomato, Capsicum, Datura, Petunia, Physalis, and tobacco, but at the time he did not make the link that local lesions on inoculated leaves were a precursor to symptoms associated with systemic infections (Allard 1912). In 1936, James Johnson (Wisconsin) also reported on the tabacum-glutinosa (F1) hybrid to study virus movement and the effects of temperature on TMV spread (Johnson 1936). In each instance, these scientists were not able to proceed beyond this F1 hybrid.

\section{STUDYING HOST PLANT RESPONSES TO TMV INFECTION}

Although frustrated with his lack of success in obtaining a fertile tabacum-glutinosa line, Holmes continued his greenhouse experiments to study the effects of TMV infection on solanaceous plants, to include dozens of crop and ornamental plant species of Nicotiana (tobacco), Solanum (eggplant, potato, and tomato), Phaseolus (bean), Physalis (tomatillo), Capsicum (pepper), Browallia, Datura (jimsonweed), Petunia, Nicandra (ground cherry), Lycium (boxthorn), Hyoscyamus (henbane), and Martynia (cat's claw) (Holmes 1932) (Fig. 3). In turn, all of the plants were assayed for infection by rub-inoculation back to $N$. glutinosa to score for necrotic local lesions.

He methodically tested, recorded, and photographed TMVinduced symptoms-ranging from necrotic lesions, systemic necrosis, masked symptoms, chlorosis, stunting, leaf distortion, leaf abscission (loss of leaves), fruit and flower drop, and spots on flowers. Holmes also determined that some plants were asymptomatic although systemically infected with TMV. Many of these symptoms and effects "characterizing virus infection" were being described for the first time (Holmes 1932). From his large greenhouse survey of TMV-infected solanaceous plants Holmes tentatively concluded, in a 1936 Phytopathology publication, that there are "tendencies of three kinds toward immunities: (a) a tendency opposing infection at the time of inoculation; (b) a tendency opposing increase of virus after infection; and (c) a tendency opposing spread of a virus" possibly representing three corresponding types of "partial resistance (a) to infection by virus, (b) to increase of virus, and (c) to spread of virus", respectively (Holmes 1932).

From at least $18 C$. annuum and $C$. frutescens cultivars inoculated with TMV, Holmes reported that most bell pepper-type plants produced primary yellowing on the inoculated leaves, followed by secondary mottling during systemic infection. In contrast, Tabasco pepper responded to TMV inoculation with necrotic local lesions and soon thereafter infected leaves abscised from the plant. When he crossed these necrotic-type peppers with mottling-type cultivars, the F1 plants inoculated with TMV produced local necrotic lesions and the leaves abscised (Fig. 4). The near infertility of these crosses was reported for Tabasco $\times$ Ruby King (bell pepper); although many seeds were produced, only two produced plants that flowered, both of which responded to TMV inoculation with necrotic lesions. Only one plant produced fruit and viable seed. From this, 48 seeds were produced and the plantlets were challenged with TMV, resulting in a 3:1 ratio of necrotic-type to mottle-type responses (Holmes 1934a, b), a typical predicted segregation ratio for a single dominant trait. Holmes used pollen from the F3 necrotic-type (abscising) plants and crossed them to commercial bell pepper varieties, including Ruby King, Golden Dawn and California Wonder to produce plants with TMV resistance. Holmes named this dominant resistance gene $L$ for local lesion response on pepper. This was, to my knowledge, the first demonstration of using Mendelian genetics to introgress a single dominant gene to produce genetic resistance to a virus in a commercial crop plant previously susceptible to systemic TMV infection.

Holmes extended this Mendelian study with crosses between Golden Dawn bell pepper $\times C$. frutescens var. minimum. He reported that the $L$ gene was not linked to heritable phenotypes such as flower color, pungency, and immature fruit color (Holmes 1934b) (Supplementary Fig. S1). When Holmes was working with pepper there was a great deal of confusion about the taxonomy of the genus Capsicum. In 1923, Liberty Hyde Bailey (Cornell) grouped C. annuum with C. frutescens (Bailey 1923), thus explaining why Holmes refers to bell pepper as $C$. frutescens (Holmes 1934a). In the mid-1950s the genus was reorganized as the $C$. annuum complex, today represented by five species: $C$. annuum, $C$. frutescens, C. bacatum, C. pubescens, and C. chinense (Bosland and Votava 2012; Heiser and Smith 1953; Mongkolporn and Taylor 2011).

Holmes also identified a minor gene for resistance $\left(l^{i}\right)$, described in a 1937 Phytopathology paper, in pepper varieties Long Red Cayenne, Sunnybrook Cheese, and Sweet Meat Glory (Holmes 1937c). This was in addition to plants with primary symptoms of necrotic lesions (Tabasco, Anaheim Chili, and Creole) (Holmes 1932). Plants with the $l^{i}$ allele had "imperfect localization" of TMV with "yellowish primary lesions with some necrosis, subsequently recovering except for scattered secondary lesions in a few plants" with yield "not much affected" (Holmes 1937c).

Holmes experimentally tested peppers with $L L, l^{i} l^{i}$, and $l l$ genetic backgrounds, as well as $L l$ and $L l^{i}$ plants and determined that they conformed to predicted Mendelian responses. Plants with "genetic constitution $l l$ show systemic chlorosis; $l^{i} l^{i}$ delayed necrosis with leaf abscission and recovery in many plants, small numbers of secondary lesions in a few; $l^{i} l$ systemic necrosis in all plants; and of $L L, L l$ and $L l^{i}$ localized necrosis and subsequent recovery" from TMV inoculation (Holmes 1937c). Both genes ( $L$ and $l^{i}$ ) became (and still are) part of the pepper breeder's toolkit. By 1938 Holmes was testing $L$-gene derived varieties in the field toward protecting the valuable pepper crop from the ravages TMV infection. These advanced $L$-gene introgressed pepper lines were "repeated[ly] inoculated by accidental contact" with farm implements and workers walking along the rows, or intentionally inoculated with sap extract from TMV-infected tobacco. Throughout this the plants "remain[ed] essentially unharmed, losing only the leaves actually inoculated" (Holmes 1937c).

Walter H. Greenleaf, a pepper breeder at the Auburn University Experiment Station, successfully introgressed "Holmes' $L$-gene" into several varieties of pepper, including pimiento (Supplementary Fig. S2). He later saved the Tabasco industry by breeding etch resistant Greenleaf Tabasco pepper (Greenleaf 1986; Greenleaf et al. 1956, 1969, 1970). Interestingly, Greenleaf also had a scientific connection with R. E. Clausen-he received his Ph.D. in genetics under the direction of Clausen at UC-Berkeley in 1941, with a research focus on Nicotiana amphidiploids toward tracing the evolution of the genus (Greenleaf 1941).

\section{N-GENE RESISTANCE IN NICOTIANA SPECIES}

Although Holmes' frustration was evident in not being able to identify a fertile tabacum-glutinosa hybrid, he methodically continued crossing Nicotiana species that had different responses 
(mottle, necrosis, and chlorosis) or $N$-gene-like responses (necrotic) to TMV inoculation (Fig. 3). Holmes used this $N$-gene designation for $N$. rustica and $N$. glutinosa to refer to a necrotic-type response. $N$. rustica had a differential response to TMV infection depending on plant age-young plants developed systemic necrosis and older plants developed localized necrosis (Holmes 1934b). Holmes was able to introgress the necrotic resistance gene $(N)$ from $N$. rustica to $N$. paniculata, a mottling-type plant, retaining this developmentally regulated genetic response to TMV. (In contrast, TMV inoculation of $N$. glutinosa resulted in necrotic local lesions in both young and old plants.) This systemic necrosis feature of the $N$. rustica $N$ gene was not desirable for the plant breeder looking for plants resistant to TMV, plus neither of these tobaccos had useful agronomic qualities. Their usefulness was in allowing Holmes to trace the genetics of resistance. The F1 plants of $N$. paniculata $\times N$. rustica var. jamaicensis crosses had a necrotic primary response to TMV challenge, with no mottled secondary response (1:0 ratio). The plants could not be self-fertilized, but backcrosses to $N$. paniculata were successful, responding to TMV challenge with a 1:1 ratio of necrotic/mottled plants. From this, Holmes made five further backcrosses using pollen from $N$. paniculata and selected plants with the necrotic-type response, at which point the plants had been

\section{FIGURE 4}

Holmes' experiments with Capsicum frutescens 'Tabasco' $\times$ C. annuum

'Ruby King' (bell pepper) interspecies hybrid plants inoculated with

Tobacco mosaic virus (TMV), as reported in Phytopathology (Holmes 1934b). A fourth generation hybrid was selected for TMV necrotic-type response ( $L$ gene) with the goal of producing high yielding commercial bell-peppers with TMV L-gene-type resistance (Holmes 1934a, b). A, B,

and $\mathbf{C}$, Plants on the left are a mottling type; plants on the right are a necrotic-type. As reported by Holmes: "A, 3 days after inoculation and

B, 7 days after inoculation of the two leaves. Inoculated leaves had fallen from [the] necrotic-type plant, freeing it from virus. C, 16 days after inoculation. Mottling-type plant was stunted and mottled. Necrotictype one was large, without symptoms and free of virus" (Holmes 1934b). (Reproduced with permission of The American Phytopathological Society.) restored in fertility. A necrotic-type plant was selfed and plants were selected by TMV challenge until Holmes obtained a homozygous line with the dominant gene $(N)$ introgressed to $N$. paniculata. As further proof of this, he made reciprocal crosses of these plants $(N N)$ with the original $N$. paniculata parent type $(n n)$-only necrotic-type plants were recovered $(\mathrm{Nn})$.

Holmes' expertise with Mendelian genetics was increasingly evident, as well as his intellectual shift to elucidate the genetics and evolution of Nicotiana within the context of host responses to TMV. He experimented with $N$. rustica $(n=24)$, which was thought to be an amphidiploid resulting from naturally occurring hybridization of $N$. undulata $(n=12)$ and $N$. paniculata $(n=12)$. From paniculatarustica crosses, Holmes identified gene $D$ (unmodified necrosis and not linked to $N$ ) from $N$. rustica that "in the presence of $N$, the gene $D$ allowed primary lesions to appear promptly, and prevented extensive yellowing of surrounding tissue" (Holmes 1936a).

As a proof-of-principle, he continued with the paniculata-rustica $(N N)$ germplasm, and by successive recurrent backcrosses to paniculata, he developed a plant indistinguishable from the $N$. paniculata parent with the exception of a $N$-gene response to TMV inoculation. This necrotic-type plant was successively crossed to $N$. tabacum and by 1937 Holmes had bridged the

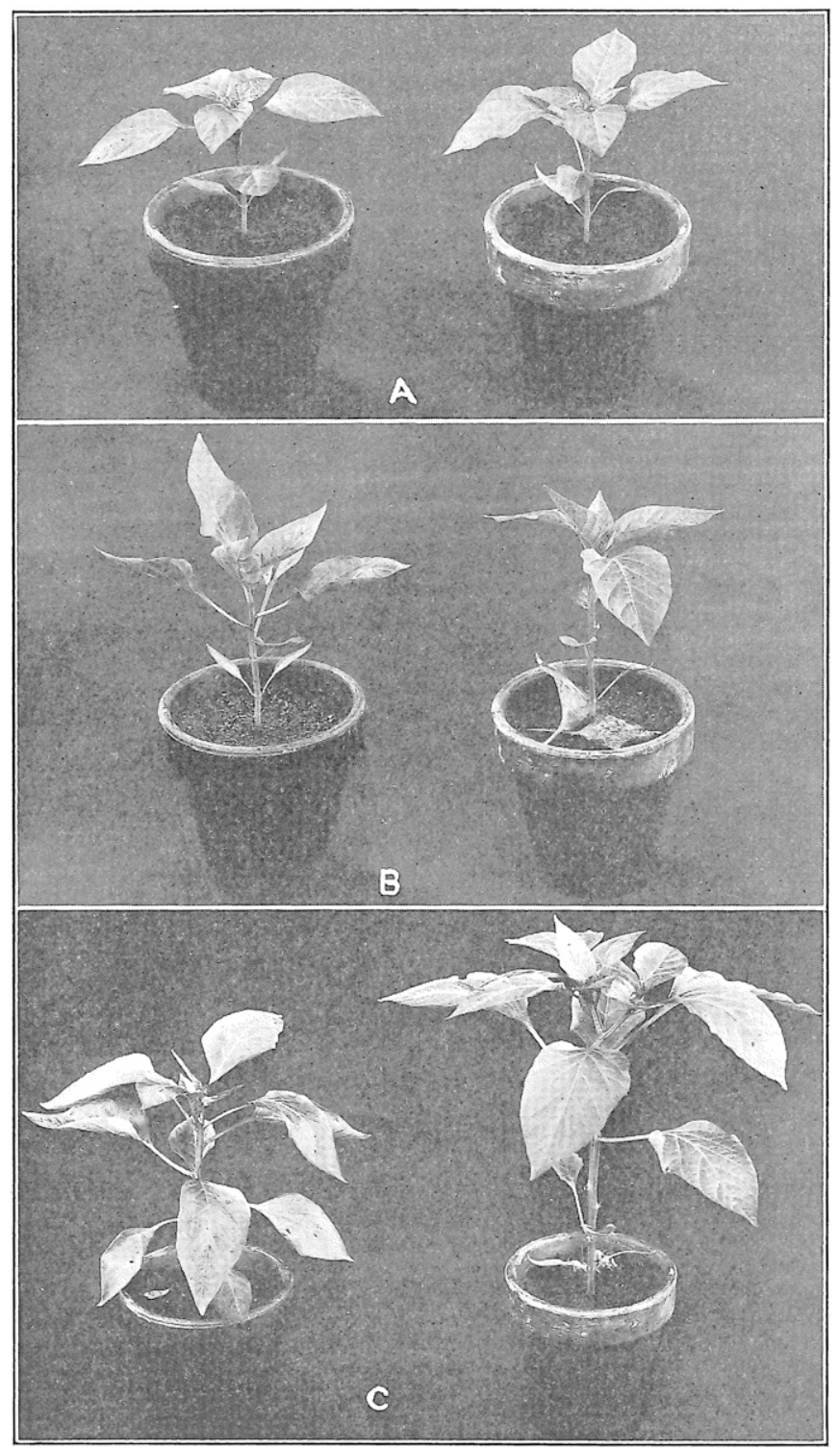


dominant $N$. rustica necrotic-response gene into the Samsoun line, suitable for crosses into commercial cultivars (Holmes 1937a, b). Throughout this time period, he continuously tried to introgress the $N$. glutinosa $N$ gene into commercial tobacco lines.

\section{DEVELOPING THE GLUTINOSA-TABACUM HYBRID}

In the early 20th century tobacco was under intensive study by American botanists and geneticists - it was a plant that was easily manipulated to study Mendelian concepts and the evolution of the genus. Specifically, the work of two UC-Berkeley plant geneticists, Roy E. Clausen and T. Harper Goodspeed, provided the solution to Holmes' dilemma of infertile F1 hybrids of tabacum-glutinosa. The Nicotiana studies at Berkeley, well-advanced by 1928, included extensive research on 56 of the known 60 species with a focus on the origin, genetics, interspecies hybridization, and determination of chromosomes in both the parent and hybrid types (Clausen 1928; Clausen and Goodspeed 1925; Clausen and Lammerts 1929; Goodspeed 1954).

In 1922 Clausen and Goodspeed crossed N. glutinosa $\times$ N. tabacum var. purpurea. The F1 glutinosa-tabacum plant produced few seeds, and only three plants grew to maturity. Two plants were "obvious" hybrids, having a small stature with "slender branches and small leaves" (Clausen and Goodspeed 1925). The flowers and leaves were similar to the $N$. glutinosa parent, but the petal "color was carmine" from N. tabacum var. purpurea. Only one plant was fertile when selfed, producing 155 seeds (F2). In 1924, the F2 material was increased at the University of California Botanical Garden at Berkeley producing plants with "remarkable robustness," forming "large plump capsules" that were easily crossed with parents of either type to produce seed (Clausen and Goodspeed 1925). For Clausen and Goodspeed the "uniformity" of the F2 population and its "close resemblance" to the F1, suggested that something was genetically amiss (Clausen and Goodspeed 1925).

Cytological examination revealed that the diameter (hence, volume) of pollen of the $\mathrm{F} 1$ and $\mathrm{F} 2$ plants was about twofold greater than the parent types. Strikingly, Clausen and Goodspeed found 36 chromosomes $(2 n=72)$, indicating that the hybrid was a double diploid, or tetraploid hybrid (Fig. 5); today this plant is described as an amphidiploid. This exceedingly rare genetic event had doubled the $N$. glutinosa $(n=12)$ and $N$. tabacum $(n=24)$ chromosomes to produce a fertile plant with 36 chromosomes. A "chromosomal formula" of $12 \mathrm{GG}+24$ TT was proposed which would result in fertile flowers, producing offspring with this double set of chromosomes (Clausen and Goodspeed 1925). This finding was of interest to geneticists and botanists, in that it proved a hypothesis put forth in 1917 by Øjvind Winge, a yeast geneticist at the Carlsberg Laboratory (Denmark), that interspecies hybridization would result in tetraploid interspecific hybrids having $2\left(n_{1}+n_{2}\right)$ chromosomes, where $n$ indicates the number of chromosomes in parental lines (Winge 1917).

Clausen determined that the morphological features of the fertile amphidiploid, retained through five experimental generations, were sufficiently different from either parent that it should be considered a new species: Nicotiana digluta "(didiploid glutinosa-tabacum), an acrostic abbreviation descriptive of its cytological and genetic constitution" (Clausen 1928) (Fig. 5). In this same paper, Clausen described fertile crosses of $N$. digluta $\times N$. tabacum, diglutatabacum $\times N$. tabacum and other combinations of crosses with N. glutinosa (Clausen 1928).

For Holmes, N. digluta resolved his "failure of repeated attempts ... for more than three years" to obtain fertile hybrids of $N$. glutinosa $\times$ N. tabacum. The solution, "a fertile amphidiploid derived from this hybrid was obtained through the kindness of Dr. R. E. Clausen" (Holmes 1938a). In 1937, in Science, Holmes published his preliminary findings that $N$. digluta $\times N$. tabacum plants produced a "uniform necrotic response" following TMV infection. The backcross $(N$. digluta $\times N$. tabacum $) \times N$. tabacum plants responded to TMV infection "with the mottling-type plants being in excess of expected," reflecting the nonstandard segregation genetics of such crosses. In this first report of moving the glutinosa $N$ gene to $N$. tabacum, through the amphidiploid N. digluta, Holmes stated his conclusions and goals:

"It is not yet known whether these necrotic-type genes characteristic of $N$. rustica and $N$. glutinosa can be incorporated in [commercial] strains of $N$. tabacum. The work here reported is being continued with a view to securing an answer to this problem, because it is believed that tobacco mosaic would be unable to maintain itself in tobacco varieties bearing these genes, and that this disease, now prevalent in such other
FIGURE 5

The phenotypic outcome of the rare event of the amphidiploid Nicotiana digluta. This work was described by R. E. Clausen and T. H. Goodspeed, plant geneticists at the University of California-Berkeley, who made it possible for Holmes to proceed with his $\mathrm{N}$-gene experiments. The original figure legend: " $\mathbf{A}$, Nicotiana glutinosa $\left(24_{\mathrm{GG}}\right) ; \mathbf{B}$, normal F1 glutinosatabacum $\left(12_{\mathrm{G}}+24_{\mathrm{T}}\right) ; \mathbf{C}, \mathrm{N}$. digluta $\left(12_{\mathrm{GG}}+24_{\mathrm{TT}}\right) ; \mathbf{D}$, N. tabacum (24T). Background ruled in $\mathrm{cm}$. squares. Note that $N$. digluta is simply an enlarged expression of normal F1 glutinosa-tabacum, aside from fertility, which is evidenced by abundant pollen production" (Clausen 1928)

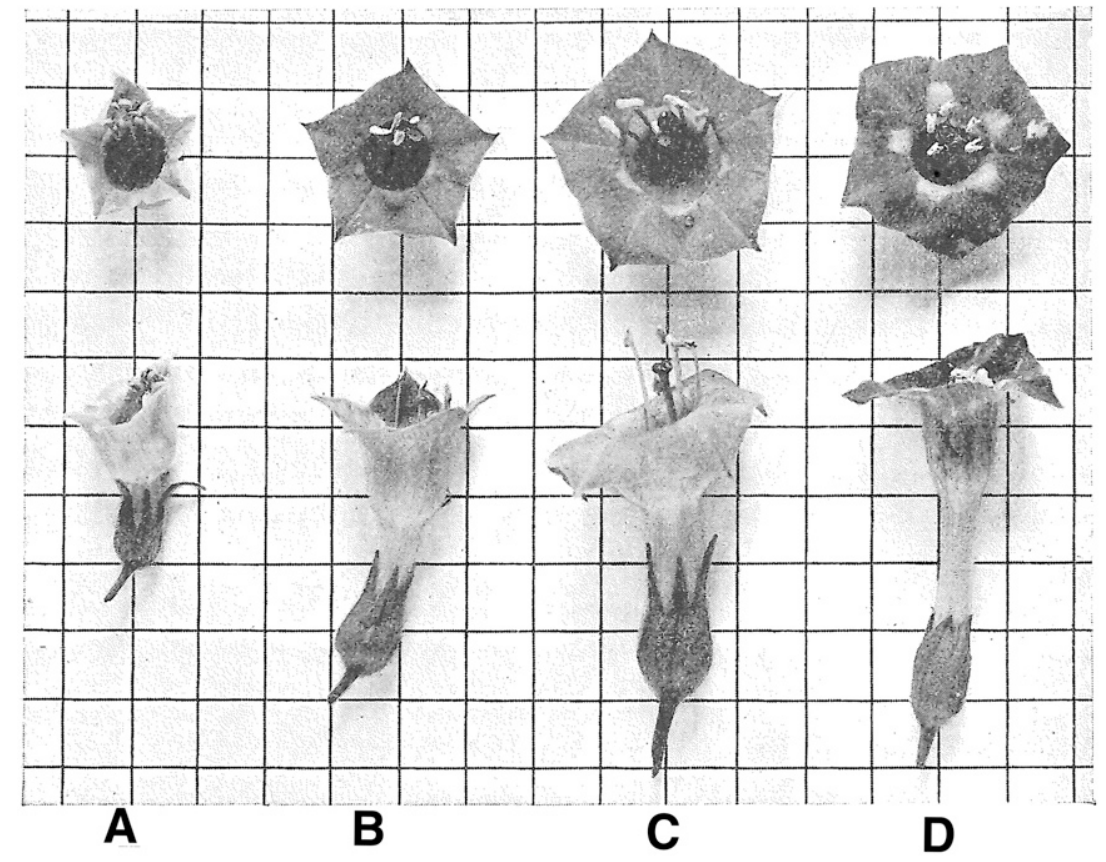


crops as tomatoes and peppers, might disappear if the virus reservoir in tobacco were eliminated or considerably reduced" (Holmes 1937a).

The following year, in Phytopathology, Holmes reported his success with crossing $N$. digluta with $N$. tabacum var. Connecticut Broadleaf and obtaining fertile F1 plants-all of which produced necrotic local lesions following challenge with TMV. He then backcrossed these F1 $\mathrm{N}$-gene containing tobaccos with three commercial varieties: Connecticut Broadleaf, White Burley, and Samsoun tobacco. The results "tended" toward the expected $N$-gene ratios of 1:1 for backcrossed plants and 3:1 for selfed plants, with the exception of Connecticut Broadleaf (Fig. 6). However, the inability to obtain homozygous $\mathrm{N}$-gene Burley (Ky16) backcross lines was less problematic for growers as the $N n$ and $N N$ lines both had necrotic responses to TMV challenge. $N$. tabacum var. Samsoun B4 plants with the $N$ gene were "fully fertile with innumerable tobacco varieties now grown" (Holmes 1938b) and would be used as the basis for further crosses. In 1940, Valleau released NN Burley to growers and within a decade "during which time many thousands of acres of mosaic-resistant tobacco have been grown in Kentucky, it can be stated that this type of resistance is completely satisfactory as a means of controlling all strains of the common tobacco mosaic virus tested" (Valleau 1952). For the Burley and Samsoun crosses a recombination event likely occurred early, resulting in the $N$ gene being incorporated into the $N$. tabacum chromosome- that was also in the $N$. digluta background. In time, a backcrossed plant will have a full complement of the N. tabacum background plus the $N$ gene chromosome from $N$. glutinosa. In contrast, for the Connecticut Broadleaf material there presumably was no recombination event and with successive backcrossing, the $N$ gene and other glutinosa chromosomes can be lost due to a lack of pairing.

Holmes also reported the $N$-gene-based genetics held for all strains of TMV that he tested, thus providing empirical proof that the $N$ gene had been introgressed, achieving his goal: "so little virus can be extracted from the necrotic lesions ... that transfer from plant to plant in the field becomes negligible. Practical usefulness of hypersensitivity as a form of resistance depends on this paucity of available virus within the crop" (Holmes 1954). After 6 years Holmes had realized the first part of his stated intent in 1931-to control the virus load in commercial tobacco through the use of genetics toward protecting pepper and tomato from TMV infection. By 1938, with the $L$ and $N$ genes, Holmes had demonstrated and shown how to deploy the gene-for-gene interaction using TMV as a "hereditary unit" and a local lesion bioassay to follow the introgression of dominant host genes for resistance to crop plants (Holmes 1934b, 1936a; Holmes 1936b, 1937a, b, c, 1938a). This was at least a decade before H. H. Flor posited: "For each gene conditioning resistance in the host there is a specific gene conditioning pathogenicity in the parasite" from his flax rust studies (Flor 1956). In my search of the literature, to date, I have not found evidence that Flor cited Holmes. As late as 1971 in his oft cited article in the Annual Review of Phytopathology, Flor wrote only of a Hessian fly-wheat gene-for-gene interaction, with a mere suggestion that analogous "relationships may exist between other insects, nematodes, bacteria, and viruses and their plant hosts" (Flor 1971).

The path was now set for tobacco breeders to incorporate the $N$ gene into economically sought after cultivars. W. D. Valleau joined the University of Kentucky as a tobacco breeder and pathologist in 1919, after obtaining a Ph.D. in plant pathology from the University of Minnesota. Valleau reported that the commercial TMV resistant tobacco lines he produced from Holmes' material were in growers' fields by 1940, and "the value of the NN factors as a means of controlling tobacco mosaic became clearly evident" (Valleau 1952). As Holmes noted, this outcome "though envisaged first and long delayed in accomplishment" set the stage to "eliminate the reservoir" of TMV "in tobacco and tobacco products, the usual sources of infection both for succeeding [tobacco] crops and for other crops

Ratios of necrotic-type to chlorotic-type plants among derivatives of Nicotiana digluta Clausen and Goodspeed

\begin{tabular}{|c|c|c|c|c|}
\hline $\begin{array}{c}\mathrm{F}_{1} \text { hybrid and } \\
\text { backeross generations }\end{array}$ & $\begin{array}{l}\text { Number of } \\
\text { times with } \\
\text { N.tabacum } \\
\text { as parentc }\end{array}$ & $\begin{array}{l}\text { Connecticut } \\
\text { Broadleaf } \\
\text { backeross } \\
\text { line }\end{array}$ & $\begin{array}{l}\text { Burley } \\
\text { (Burley 16) } \\
\text { backeross } \\
\quad \text { line }\end{array}$ & $\begin{array}{c}\text { Samsoun } \\
\text { backeross } \\
\text { line }\end{array}$ \\
\hline $\begin{array}{r}N . \text { digluta } \times \\
N . \\
\mathrm{B}_{1}\end{array}$ & $\begin{array}{l}2 \\
3 \\
4 \\
5 \\
6\end{array}$ & $\begin{aligned} 132 & : 0 \\
121 & : 504 \\
17 & : 247 \\
23 & : 286 \\
63 & : 185\end{aligned}$ & $\begin{array}{r}272: 269 \\
99: 148 \\
123: 120 \\
156: 115\end{array}$ & $\begin{aligned} 310: & 357 \\
93: & 171 \\
96: & 149 \\
120: & 135\end{aligned}$ \\
\hline Selfed generations ${ }^{b}$ & $\begin{array}{l}\text { Number of } \\
\text { times } \\
\text { selfed }\end{array}$ & $\begin{array}{l}\text { Connecticut } \\
\text { Broadleaf } \\
\text { selfed line }\end{array}$ & $\begin{array}{l}\text { Burley } \\
\text { selfed } \\
\text { line }\end{array}$ & $\begin{array}{l}\text { Samsoun } \\
\text { selfed } \\
\text { line }\end{array}$ \\
\hline $\begin{array}{l}\mathrm{F}_{2} \\
\mathrm{~F}_{3}\end{array}$ & $\begin{array}{l}1 \\
2 \\
3\end{array}$ & $\begin{array}{l}310: 144 \\
271: 182 \\
123: 79\end{array}$ & $\begin{array}{l}325: 136 \\
328: 121 \\
347: 128\end{array}$ & $\begin{array}{l}324: 110 \\
399: 0 \\
303: 0\end{array}$ \\
\hline
\end{tabular}

a Beginning with the necrotic-type hybrid $N$. digluta $\times N$. tabacum variety Connecticut Broadleaf, backerosses were made to the three varieties of $N$. tabacum, Connecticut Broadleaf, Burley, and Samsoun, a necrotic-type hybrid of the preceding generation being used as o parent, $N$. tabacum as of parent in each ease.

$\mathrm{b}$ Beginning with a necrotic-type plant of $\mathrm{B}_{1}$ as origin in each series, a series of filial generations was produced, using a necrotic-type plant of the preceding generation as parent in each case.

c Because $N$. digluta itself originally had $N$. tabacum as one parent, and carried a full set of $N$. tabacum chromosomes, the numbers in this column are larger by one than is usually the case for hybrids of the indicated generations.

\section{FIGURE 6}

Tabulated results from recurrent backcrosses and self-fertilization generations derived from Nicotiana digluta $\times$ N. tabacum toward deriving commercial lines of Connecticut Broadleaf, Burley, and Samsoun tobacco (Holmes 1938a). The introgression of the N. glutinosa N gene was made possible with N. digluta, a naturally occurring amphidiploid identified by Clausen and Goodspeed at the University of California-Berkeley (Clausen 1928). (Reproduced with permission of The American Phytopathological Society.) 
susceptible to tobacco-mosaic disease" (Holmes 1938a). After of decade of intensive research, Holmes had achieved his goal.

\section{CONCLUDING REMARKS}

The foundational narrative for plant pathologists is that Holmes moved straightaway from concept to practice: the necrosis was a resistance response in $N$. glutinosa, the $N$ gene was the dominant resistance gene, it was introgressed into commercial tobacco, and TMV was controlled in the field. This is not incorrect per se, but as the historian of science Robert E. Kohler pointed out for the invention of the Drosophila map, this narrative "fail[s] to show how conceptual changes were driven by practical imperatives of doing experiments" (Kohler 1994). For Holmes, the experimental difficulty in moving the $N$ gene from $N$. glutinosa to $N$. tabacum consumed more than 3 years and was finally resolved by plant scientists at the University of California who had identified $N$. digluta for completely unrelated purposes - a clear deviation from the foundational narrative. Critically, what is lost in the foundational narrative is how Holmes used Mendelian genetics to develop plants resistant to TMV infection in other solanaceous plants, including noncommercial tobaccos $(N$. rustica $\times N$. paniculata) to demonstrate the proof of principle of the $N$ gene. And importantly, with the $N$. glutinosa work stalled, he had particular success with the $L$ gene he identified in Capsicum frutescens 'Tabasco' - that spices up the history of $N$-gene resistance.

Holmes is known by plant pathologists and virologists for his $N$-gene research with tobacco, but his prior work (Holmes 1934b) of genetic crosses between TMV-susceptible (mottling type, $l l$ ) and resistant (local lesion type, $L L$ ) Capsicum species deserves renewed attention. In $C$. frutescens, Holmes had discovered "a dominant Mendelian genetic factor that causes localization of tobaccomosaic virus in inoculated leaves" (Holmes 1934b). This, he believed, was "the first description of such a genetic factor affecting a virus disease in its plant hosts" (Holmes 1934b), and he extended this finding by experimentally showing that the $L$ gene was not linked to seven readily observable traits in pepper, such as flower color, and pungency, and these hybrids were fully fertile.

In later years, the identification of Holmes' $N$ gene became a much sought after trophy for several generations of virologists (Dunigan et al. 2007). What was this gene? How did it manifest resistance? Was it related to other resistance genes? In 1994, with molecular genetic methods the $N$ gene was identified. When genomic DNA with the full-length $N$ gene was used to transform TMV-susceptible tobacco and tomato plants, necrotic local lesions developed following challenge with TMV and this $\mathrm{N}$-gene resistance was temperature sensitive (Dinesh-Kumar et al. 1995; Whitham et al. 1994, 1996). It was shown that two products, a $131-\mathrm{kDa}$ protein containing the TIR-NBS-LRR domain and an alternatively spliced transcript encoding a $75-\mathrm{kDa}$ protein with a truncated LRR domain, are necessary for a proper resistance response in transgenic tobacco and tomato (Dinesh-Kumar and Baker 2000). Interestingly, a recent study of $N$. edwardsonii, an amphidiploid of $N$. glutinosa $\times N$. clevelandii, revealed the conservation of evolution of resistance genes: transgenic $N$. edwardsonii plants designed to silence the $N$ gene exhibited an increased susceptibility to tombusviruses as well as TMV (Balaji et al. 2007). A second study showed that the tombusvirus resistance gene present in N. edwardsonii segregated independently from the $N$ gene (Schoelz et al. 2006). An analysis of resistance gene homologs in $N$. glutinosa, the source of the $N$ gene as well as the tombusvirus resistance gene, suggested the presence of approximately 8 to $10 \mathrm{~N}$-related homologs (Balaji et al. 2007; Whitham et al. 1994; Yuan et al. 2015). Taken altogether, these studies indicate the conservation of an $\mathrm{N}$-gene family of resistance genes, of which the tombusvirus resistance gene is a member. Furthermore, it suggests the possibility of developing a synthetic $N$ gene(s) to induce an HR-like response following multifamily virus infections in crop plants once the basis of specificity is determined.

Oddly enough, today only $10 \%$ of the tobacco growers use lines with $\mathrm{N}$-gene resistance, attributing the glutinosa background with "yield drag" in flue-cured tobacco breeding lines. Recently, a demonstration of these negative effects was confirmed by expression of the $\mathrm{N}$-gene alone in transgenic TMV susceptible tobacco lines (Lewis et al. 2007). In contrast, the introgression of Holmes' $L$ gene to pepper cultivars is not linked with yield-drag, is effective for control of TMV, and is used by commercial producers as well as home gardeners.

My intent here has been to use a case study approach to show that the events leading up to scientific success stories often provide a much richer narrative-in this instance navigating space between the lab and the field, in which a practical idea developed by Holmes to protect the pepper and tomato crops was predicated on (i) the success of unrelated work of Berkeley scientists interested in the evolutionary genetics of speciation toward developing a better taxonomy of the genus Nicotiana; (ii) a willingness by Holmes to concurrently investigate host-virus outcomes in pepper and additional solanaceous plant species, resulting in the discovery of additional dominant resistance genes; and (iii) Holmes' collaboration with pepper and tobacco pathologist-breeders at Auburn and Kentucky to bring $L$ - and $N$-gene resistance to field crops.

\section{ACKNOWLEDGMENTS}

I thank J. Starr and J. Schoelz for explaining to me the peculiar genetics of amphidiploids. The critical comments and suggestions made by H. Scholthof, J. Schoelz, and J. Pyle are much appreciated. I thank W. Cody for growing the Glurk tobacco plants and preparing inoculum. I appreciate the resources provided by the School for Global Environmental Sustainability at Colorado State University where I was a Visiting Fellow in 2016. Funding was provided in part by The Association of Former Students at Texas A\&M University and the National Science Foundation under Grant 2015-1456878.

\section{LITERATURE CITED}

Allard, H. A. 1912. The mosaic disease of tobacco. Science 36:875-876

Allard, H. A. 1914. The mosaic disease of tobacco. Bull. No. 40. U.S. Department of Agriculture, Bureau of Plant Industry, Washington, D. C.

Allard, H. A. 1916. A specific mosaic disease in Nicotiana viscosum distinct from the mosaic disease of tobacco. J. Agric. Res. 7:481-486.

Allen, G. E. 1991. History of agriculture and the study of heredity: A new horizon. J. Hist. Biol. 24:529-536.

Babcock, E. B., and Clausen, R. E. 1918. Genetics in Relation to Agriculture. McGraw-Hill, New York.

Bailey, L. H. 1923. Capsicum. Gentes Herbarium 1:128-129.

Balaji, B., Cawly, J., Angel, C., Zhang, Z., Palanichelvam, K., Cole, A., and Schoelz, J. 2007. Silencing of the $N$ family of resistance genes in Nicotiana edwardsonii compromises the hypersensitive response to tombusviruses. Mol. Plant-Microbe Interact. 20:1262-1270.

Bosland, P. W., and Votava, E. J. 2012. Peppers: Vegetable and Spice Capsicums. CABI, Cambridge, MA.

Campbell, C. L., Peterson, P. D., and Griffith, C. S. 1999. The Formative Years of Plant Pathology in the United States. The American Phytopathological Society, St. Paul, MN.

Christensen, C. M. 1984. E. C. Stakman, Statesman of Science. The American Phytopathological Society, St. Paul, MN.

Clausen, R. E. 1928. Interspecific hybridization in Nicotiana. VII. The cytology of hybrids of the synthetic species, digluta, with its parents glutinosa and tabacum. Pages 177-211 in: University of California Publications in Botany, vol. XI, 1922-1930. W. A. Setchell, R. M. Holman, and T. H. Goodspeed, eds. University of California Press, Berkeley.

Clausen, R. E., and Goodspeed, T. H. 1925. Interspecific hybridization in Nicotiana. II. A tetraploid glutinosa-tabacum hybrid, an experimental verification of Winge's hypothesis. Genetics 10:278-284.

Clausen, R. E., and Lammerts, W. E. 1929. Interspecific hybridization in Nicotiana. X. Haploid and diploid merogony. Am. Nat. 63:279-282. 
Corner, G. W. 1964. A History of The Rockefeller Institute, 1901-1953: Origins and Growth. Rockefeller University Press, New York.

Creager, A. N. H. 2002. The Life of a Virus: Tobacco mosaic virus as an Experimental Model, 1930-1965. University of Chicago Press, Chicago.

Dinesh-Kumar, S. P., and Baker, B. J. 2000. Alternatively spliced $N$ resistance gene transcripts: Their possible role in tobacco mosaic virus resistance. Proc. Natl. Acad. Sci. USA 97:1908-1913.

Dinesh-Kumar, S. P., Whitham, S., Choi, D., Hehl, R., Corr, C., and Baker, B. 1995. Transposon tagging of tobacco mosaic virus resistance gene $N$ : Its possible role in the TMV- $N$-mediated signal transduction pathway. Proc. Natl. Acad. Sci. USA 92:4175-4180.

Dunigan, D. D., Golemboski, D. B., and Zaitlin, M. 2007. Analysis of the $N$ gene of Nicotiana. Pages 120-135 in: Ciba Foundation Symposium 133-Plant Resistance to Viruses. D. Evered and S. Harnett, eds. John Wiley \& Sons, Chichester, UK.

Fitzgerald, D. K. 1990. The Business of Breeding Hybrid Corn in Illinois, 1890-1940. Cornell University Press, Ithaca.

Flor, H. H. 1956. The complementary genic systems in flax and flax rust. Adv. Genet. 8:29-54

Flor, H. H. 1971. Current status of the gene-for-gene concept. Annu. Rev. Phytopathol. 9:275-296.

Goodspeed, T. H. 1954. The Genus Nicotiana: Origins, Relationships and Evolution of Its Species in the Light of Their Distribution, Morphology and Cytogenetics. Chronica Botanica Co., Waltham, MA.

Greenleaf, W. H. 1941. Sterile amphidiploids: Their possible relation to the origin of Nicotiana tabacum. Am. Nat. 75:394-399.

Greenleaf, W. H. 1986. The tabasco story. HortScience 10:98.

Greenleaf, W. H., Cook, A. A., and Heyn, A. N. J. 1956. Inheritance of resistance to tobacco-etch virus in Capsicum frutescens and in Capsicum annum. Phytopathology 46:371-375.

Greenleaf, W. H., Hollingsworth, M. H., Harris, H., and Rymal, K. S. 1969. Bighart: Improved variety of pimiento pepper. Auburn Univ. Agric. Exp. Stn. Leaflet No. 78:1-8.

Greenleaf, W. H., Martin, J. A., Lease, J. G., Sims, E. T., and Van Blaricom, L. O. 1970. Greenleaf Tabasco, a new tobacco etch virus resistant Tabasco pepper variety (Capsicum frutescens L.). Auburn Univ. Agric. Exp. Stn. Leaflet No. 81:1-10.

Heiser, C. B., and Smith, P. G. 1953. The cultivated Capsicum peppers. Econ. Bot. 7:214-227.

Holmes, F. O. 1925. The relation of Herpetomonas elmassiani (Migone) to its plant and insect hosts. Biol. Bull. 49:323-337.

Holmes, F. O. 1928a. Cytological study of the intracellular body characteristic of Hippeastrum mosaic. Bot. Gaz. 86:50-58.

Holmes, F. O. 1928b. Accuracy in comparing various concentrations of tobacco-mosaic virus. Phytopathology 18:132.

Holmes, F. O. 1928c. Ultra-violet light photography in the study of plant viruses. Bot. Gaz. 86:59-65.

Holmes, F. O. 1928d. Accuracy in quantitative work with tobacco mosaic virus. Bot. Gaz. 86:66-81.

Holmes, F. O. 1929a. Inoculating methods in tobacco mosaic studies. Bot. Gaz. 87:56-63.

Holmes, F. O. 1929b. Local lesions in tobacco mosaic. Bot. Gaz. 87:39-55.

Holmes, F. O. 1930. Local and systemic increase of tobacco mosaic virus. Am. J. Bot. 17:789-805.

Holmes, F. O. 1931. Local lesions of mosaic in Nicotiana tabacum L. Contrib. Boyce Thompson Inst. 3:163-172.

Holmes, F. O. 1932. Symptoms of tobacco mosaic disease. Contrib. Boyce Thompson Inst. 4:323-357.

Holmes, F. O. 1934a. A genetic factor for localization of tobacco-mosaic virus in Capsicum. Science 79:374.

Holmes, F. O. 1934b. Inheritance of ability to localize tobacco-mosaic virus. Phytopathology 24:984-1002.

Holmes, F. O. 1936a. Interspecific transfer of a gene governing type of response to tobacco-mosaic infection. Phytopathology 26:1007-1014.

Holmes, F. O. 1936b. Inheritance of susceptibility to mosaic disease in pepper plants. J. Bact. 31:52.

Holmes, F. O. 1937a. Genes affecting response of Nicotiana tabacum hybrids to tobacco-mosaic virus. Science 85:104-105.

Holmes, F. O. 1937b. Hereditary factors affecting tobacco-mosaic disease in solanaceous plants. Phytopathology 27:131-132.

Holmes, F. O. 1937c. Inheritance of resistance to tobacco-mosaic disease in the pepper. Phytopathology 27:637-642.

Holmes, F. O. 1938a. Inheritance of resistance to tobacco-mosaic disease in tobacco. Phytopathology 28:553-561.

Holmes, F. O. 1938b. Strains of tobacco resistant to tobacco mosaic. Phytopathology 28:9.
Holmes, F. O. 1954. Inheritance of resistance to viral diseases in plants. Adv. Virus Res. 2:1-30.

Johnson, J. 1936. A tobacco hybrid useful for virus studies. Am. J. Bot. 23: 40-46.

Kimmelman, B. A. 1987. A Progressive Era Discipline: Genetics at American Agricultural Colleges and Experiment Stations, 1900-1920. Ph.D. Dissert. University of Pennsylvania, Philadelphia.

Kloppenburg, J. R. 1985. First the Seed: A Social History of Plant Breeding and the Seed Industry in the United States. Cornell University, Ithaca.

Kohler, R. E. 1994. Lords of the Fly: Drosophila Genetics and the Experimental Life. University of Chicago Press, Chicago.

Lewis, R. S., Linger, L. R., Wolff, M. F., and Wernsman, E. A. 2007. The negative influence of $\mathrm{N}$-mediated TMV resistance on yield in tobacco: Linkage drag versus pleiotropy. Theor. Appl. Genet. 115:169-178.

Mongkolporn, O., and Taylor, P. W. J. 2011. Capsicum. Pages 43-57 in: Wild Crop Relatives: Genomic and Breeding Resources. Vegetables. C. Kole, ed. Springer, Berlin

Peterson, P. D., ed. 2001. Stem Rust of Wheat: From Ancient Enemy to Modern Foe. The American Phytopathological Society, St. Paul, MN.

Peterson, P. D. 2003. The Common Barberry: The Past and Present Situation in Minnesota and the Risk of Wheat Stem Rust Epidemics. Ph.D. Dissert. North Carolina State University, Raleigh.

Rosenberg, C. E. 1977. Rationalization and reality in the shaping of American agricultural research, 1875-1914. Soc. Stud. Sci. 7:401-422.

Rosenberg, C. E. 1997. No Other Gods: On Science and American Social Thought. Johns Hopkins University Press, Baltimore.

Rossiter, M. W. 1975. The Emergence of Agricultural Science: Justus Liebig and the Americans, 1840-1880. Yale University Press, New Haven.

Schoelz, J. E., Wiggins, B. E., Wintermantel, W. M., and Ross, K. 2006. Introgression of a tombusvirus resistance locus from Nicotiana edwardsonii var. Columbia to $N$. clevelandii. Phytopathology 96:453-459.

Scholthof, K.-B. G. 2000. Lessons in plant pathology: Tobacco mosaic virus. Plant Health Instructor. Published online. doi:10.1094/PHI-I-2000-101001.

Scholthof, K.-B. G. 2004. Tobacco mosaic virus: A model system for plant biology. Annu. Rev. Phytopathol. 42:13-34.

Scholthof, K.-B. G. 2011. TMV in 1930: Francis O. Holmes and the local lesion assay. Microbe 6:221-225.

Scholthof, K.-B. G. 2014. Making a virus visible: Francis O. Holmes and a biological assay for Tobacco mosaic virus. J. Hist. Biol. 47:107-145.

Scholthof, K.-B. G., Shaw, J. G., and Zaitlin, M. eds. 1999. Tobacco mosaic virus: One Hundred Years of Contributions to Virology. The American Phytopathological Society, St. Paul, MN

Scholthof, K.-B. G., and Peterson, P. D. 2006. The role of Helen Purdy Beale in the early development of plant serology and virology. Adv. Appl. Microbiol. 59:221-241.

Smocovitis, V. B. 2009. The "Plant Drosophila": E. B. Babcock, the genus Crepis, and the evolution of a genetics research program at Berkeley, 1915-1947. Hist. Stud. Nat. Sci. 39:300-355.

Summers, W. C. 2014. Inventing viruses. Annu. Rev. Virol. 1:25-35.

Valleau, W. D. 1942. Control of the common mosaic disease of tobacco by breeding. Phytopathology 32:1022-1025.

Valleau, W. D. 1952. Breeding tobacco for disease resistance. Econ. Bot. 6: 69-102.

van Helvoort, T. 1991. What is a virus? The case of tobacco mosaic disease. Stud. Hist. Philos. Sci. 22:557-588.

van Helvoort, T. 1993. Research Styles in Virus Studies in the Twentieth Century: Controversies and the Formation of Consensus. Ph.D. Dissert., University of Limburg, Maastrict.

van Helvoort, T. 1996. When did virology start? ASM News 62:142-145.

Whitham, S., Dinesh-Kumar, S. P., Choi, D., Hehl, R., Corr, C., and Baker, B. 1994. The product of tobacco mosaic virus resistance gene $N$ : Similarity to Toll and the interleukin-1 receptor. Cell 78:1101-1115.

Whitham, S., McCormick, S., and Baker, B. 1996. The $N$ gene of tobacco confers resistance to tobacco mosaic virus in transgenic tomato. Proc. Natl. Acad. Sci. USA 93:8776-8781.

Winge, $\varnothing$. 1917. The chromosomes: Their numbers and general significance. Compt. Rend. Lab. Carlsberg 13:131-275.

Yuan, X., Yan, C., Wu, Z., Ren, F., Zhang, H., Baker, B., Chen, J., and Kuang, H. 2015. Frequent gain and loss of resistance against Tobacco mosaic virus in Nicotiana species. Mol. Plant 8:1813-1815.

Zaitlin, M. 1998. The discovery of the causal agent of the tobacco mosaic disease. Pages 105-110 in: Discoveries in Plant Biology. S.-D. Kung and S. F. Yang, eds. World Scientific Publishing Co. Ltd., Hong Kong. 